\title{
Induction of programmed cell death by Prangos uloptera, a medicinal plant
}

\author{
SABER ZAHRI*, SEYED MEHDI RAZAVI, FARSHAD HASSANZADEH NIRI \\ and SARIEH MOHAMMADI
}

Cell and Molecular Laboratory, Department of Biology, Faculty of Science, University of Mohaghegh Ardabili, Ardabil, Iran

\begin{abstract}
Inhibition of the cell growth or induction of cell death is the most promising area in cancer therapy. The induction of apoptosis by dichloromethane extract of Prangos uloptera was evaluated on the McCoy cell line. This plant's roots, aerial parts and fruit have medicinal value. Cell growth inhibitory and cell cytotoxicity effects of the extract were assayed by MTT and Trypan-blue tests, respectively. Morphological changes and DNA fragmentation were also evaluated. The viability tests showed 0.49 and $0.3 \mathrm{mg} / \mathrm{ml}$ as $50 \%$ inhibition concentration and $50 \%$ cytotoxicity concentration after 24 hours of treatment, respectively. Fluorescent microscopy analysis revealed chromatin fragmentation and scanning electron microscopy showed cell shrinkage and cytoplasmic blebbing. These findings were confirmed by DNA fragmentation analysis. The results demonstrated efficient induction of apoptosis by the plant extract in moderate concentrations, but administration of higher concentrations showed that the primary manner of cell death was necrosis.
\end{abstract}

Key terms: Apoptosis, cytotoxicity, McCoy, Prangos uloptera.

\section{INTRODUCTION}

Programmed cell death or apoptosis is a genetically controlled operation leading to cell death in response to environmental or developmental signals. Cytoplasmic blebbing, cell shrinkage, chromatin condensation and nucleosomal fragmentation are the outstanding morphological characteristics of apoptosis (Wyllie et al, 1980a). Regulation of apoptosis induction is critical for normal development and tissue homeostasis, physiological processes in maturation, embryogenesis, and normal tissue turnover, as well as cancer therapy. Disruption of this process can have severe consequences (Jacobson et al, 1997). Too many cells dying may produce neurodegenerative diseases and impaired development, while insufficient cell death can lead to increased susceptibility to cancer and sustained viral infection (Watters \& Lavin, 2005). The mechanisms of killing and degrading cells via apoptosis are expressed constitutively and is activated through various stimuli (Rodriguez-Nieto \& Zhivotovsky, 2006). Many antitumor agents, such as cisplatin, mitomycin, and actinomycin D have been reported to induce an apoptotic type of death in susceptible cells, thus apoptosis in tumor cells plays a critical role in killing tumor cells during cancer therapy (Adjei \& Rowinsky, 2003).

In a previous report, we described the antiproliferative potential of some $P$. uloptera roots (Razavi et al, 2009a). We also revealed that the plant's roots were dominated by a coumarin compound that could be responsible for the observed biological activity of plant (Razavi et al, 2009b) The present study investigated the conditions and morphological and molecular properties of apoptosis induction using $P$. uloptera root extract on the McCoy cell line. This is the first report of apoptosis induction by extracts of Prangos uloptera.

\footnotetext{
* Corresponding author: Saber Zahri Department of Biology, Faculty of Sciences, University of Mohaghegh Ardabili, Ardabil, Iran, Email: zahri@uma.ac.ir,Tel : +989144544451,Fax: +984515514701
} 


\section{MATERIALS AND METHODS}

\section{Cell line and culture conditions}

The McCoy cell line was obtained from the national cell bank of Iran (NCBI: C123). The cell culture was maintained in an RPMI 1640 (Gibco) medium supplemented with $10 \%$ fetal bovine serum, $100 \mathrm{U} / \mathrm{ml}$ penicillin and $100 \mathrm{mg} / \mathrm{ml}$ streptomycin in $25 \mathrm{~cm}^{2}$ culture flasks at $37^{\circ} \mathrm{C}$ in a humidified atmosphere with $5 \% \mathrm{CO}_{2}$. In the following assays, all cells had a passage number of 3-5.

\section{Plant materials}

Plant material preparation and the plant root extraction with dichloromethane (DCM) were carried out exactly as described by Razavi et al, (2009a).

\section{Analysis of cell viability}

Cell viability and antiproliferative effects of the plant extracts were evaluated by the reduction of MTT and trypan blue exclusion assay (Freshney, 2005; Hansen et al, 1989; Vian et al, 1995).

McCoy cells in exponential growth stage were harvested from culture and resuspended in a fresh medium. The cell suspension was dispensed into 24-well microplates at $3 \times 10^{5}$ cell/well. After being cultured for $24 \mathrm{~h}$, the cells were immediately treated with various doses $(1,0.5,0.4,0.3$, 0.2 and $0 \mathrm{mg} / \mathrm{ml}$ ) of the plant extract for another 4,8 and $24 \mathrm{~h}$. The experiments were performed in triplicate to confirm the accuracy of the results.

Cell viability was evaluated by MTT (Sigma cat. 2128) colorimetric technique and $\mathrm{OD}_{570}$ was measured using a spectrophotometer (Doyle \& Griffith, 1998; Zhang et al, 2004). The wells containing only RPMI-FCS and MTT were used as the control. The $\mathrm{IC}_{50}$ values $(50 \%$ inhibition concentration) were defined as the concentration of an agent to induce 50\% reduction in the absorbance. Viability percentage was evaluated as $\mathrm{OD}_{\text {treatment }} /$ $\mathrm{OD}_{\text {control }}$ (Yeldjou, 2006).

In order to evaluate cell membrane integrity and direct counting of living and dead cells, trypan blue assay was performed. In this method, 300 dead and living cells per sample were counted and cytotoxicity was calculated as follow: Cytotoxicity $(\%)=[($ dead cell number $/$ total cells $) \times 100]$. The $\mathrm{CC}_{50}$ values $(50 \%$ Cytotoxicity Concentration) were defined as the concentration of an agent to induce $50 \%$ cell death.

\section{Morphological assessment of apoptotic cells}

An inverted phase contrast microscope was used to observe the morphological changes of the cells. For this purpose, cells were inoculated at $3 \times 10^{5}$ cell/well in 24 well microplates and treated the same as in abovementioned manner. Other culture wells were treated by Actinomycin $\mathrm{D}(50 \mu \mathrm{M})$ and $\mathrm{H}_{2} \mathrm{O}_{2}$ $(100 \mu \mathrm{M})$ as positive control of apoptosis and necrosis, respectively, and some culture wells were prepared without any treatment as negative control. After being cultured for $16 \mathrm{~h}$, the culture media was removed and cells were fixed and stained by the standard hematoxylin-eosin method. The prepared samples were photographed at $\times 100$.

\section{Scanning electron microscopy (SEM)}

McCoy cells grown on glass coverslips were incubated with the above mentioned concentration of the plant extract for 16 h. The treated and untreated cells were fixed according to Qi, et al. (2005). The coverslips were photographed directly without coating, under fixed aperture and by a Quarter backscatter detector on a Leo- $1430 \mathrm{VP}$ Scanning electron microscope.

\section{Morphological assessment of apoptotic cell nucleus}

For assessment of the cell nucleus change in apoptotic cells, the above mentioned treated cells were fixed according to (Hong et $a l, 2000)$ and stained by ethidium bromide/ Acridin orange (EtB/AO) according to Ribble et al (2005). Stained cells were washed in PBS and observed under a fluorescent microscope. 


\section{DNA fragmentation analysis}

The cells in the culture flask were treated with DCM extract of $P$. uloptera roots during exponential growth for $16 \mathrm{~h}$. The DNA was extracted from the cells using a DNP- DNA isolation kit (Cinagene, Iran) according to the supplier's manual, and then $10 \mu \mathrm{l}$ of the extract was loaded onto a $1.5 \%$ agarose gel. Actinomycin D-treated cells were used as positive control of apoptosis.

\section{RESULTS}

In this study, the exponentially growing McCoy cell line was treated with different concentrations of the DCM-extract of $P$. uloptera roots ranging from 0.2 to $1 \mathrm{mg} / \mathrm{ml}$, and cell viability was measured by MTT and trypan blue assay. The results showed that the viability of McCoy cells was clearly inhibited in a time and dosedependent manner. MTT assay indicated that different concentrations of the extract reduced the viability of McCoy cells after 4,8 and $24 \mathrm{~h}$ of incubation with $\mathrm{IC}_{50}$ value of $1.08,0.59$ and $0.49 \mathrm{mg} / \mathrm{ml}$, respectively. The cells treated with $1 \mathrm{mgmL}^{-1}$ DCM- extract at 4,8 and $24 \mathrm{~h}$ exhibited the viability of 60,30 and $20 \%$, respectively. A $100 \%$ cytotoxicity was found when the extract concentrations were increased to above $1 \mathrm{mg} / \mathrm{ml}$ (Figure 1).

Interestingly, direct counting for dead and living cells using the trypan-blue exclusion test depicted that $100 \%$ of treated cells at the concentration of $1 \mathrm{mg} / \mathrm{ml}$ absorbed the dye. The results showed a $\mathrm{CC}_{50}$ value of 0.4 and $0.3 \mathrm{mg} \mathrm{mL}^{-1}$ for $8 \mathrm{~h}$ and $24 \mathrm{~h}$ of treatment, respectively.

Morphological study of cell shape changes was performed by direct microscopy, hematoxylin and eosin staining, $\mathrm{AO} /$ Etb staining and scanning electron microscopy analysis. Using an inverted phase-contrast microscope $(400 \mathrm{X})$, it was found that the untreated cells exhibited normal shapes, with clear outline. However, the growth of the DCM-extract-treated cells was obviously inhibited. The extract-treated cells were round, inter cellular connection became loose, proliferation was inhibited and slowed and the granules in cytoplasm increased (Figure 2, 1A-1C).

To further examine morphological changes, the treated cells were stained with haematoxylin and eosin. The shape of control cells was normal and the nuclei

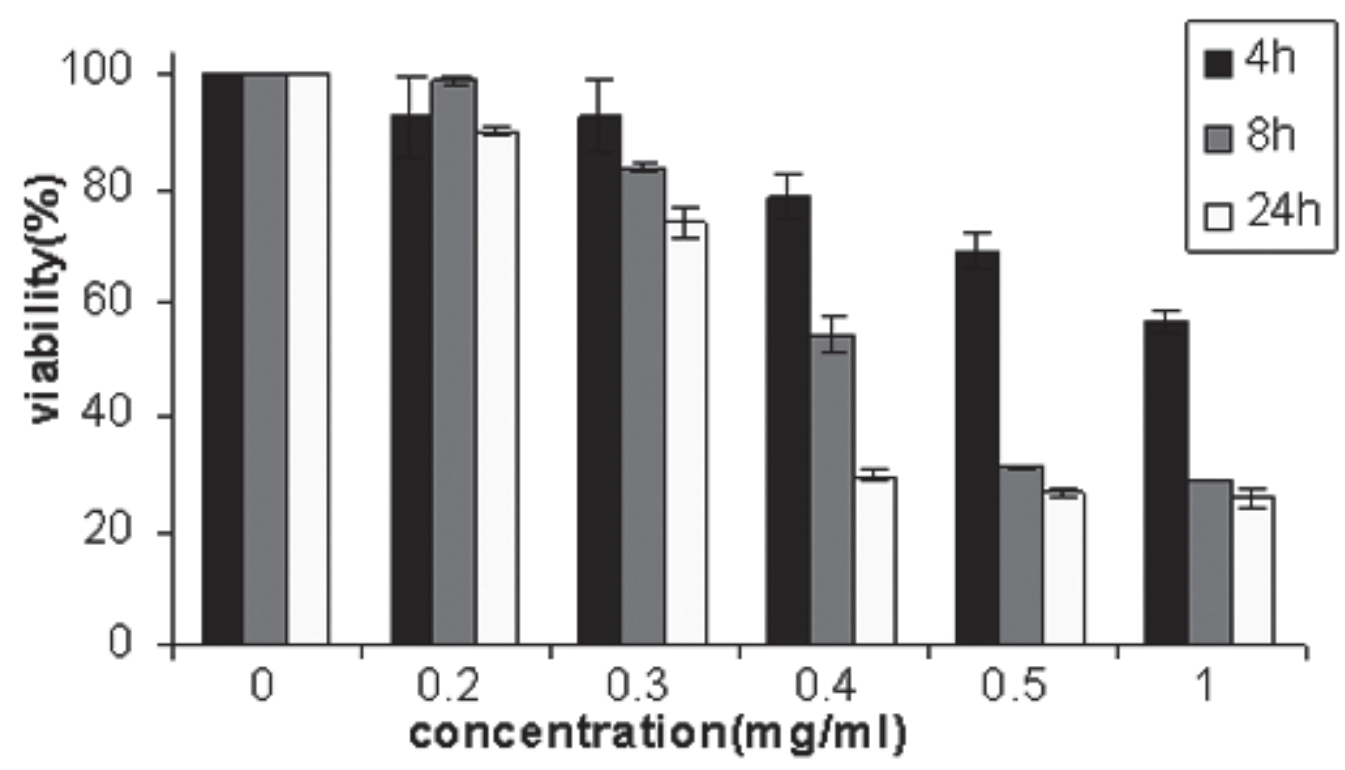

Fig. 1: The effects of DCM-extract of P. uloptera on McCoy cell lines that were measured using MTT cell viability assay. Bars indicate standard errors of the mean. 
were round, homogeneous and dark blue, while the cells treated with 0.4 and $0.5 \mathrm{mg} /$ $\mathrm{ml}$ after $24 \mathrm{~h}$ exhibited typical characteristic of apoptosis, such as nuclear condensation and fragmentation that was stained dark blue, as shown in positive control of apoptotic cells (Figure 2, 2A2C).

In order to evaluate nucleus morphology alteration and chromatin fragmentation, treated and control cells were stained using $\mathrm{EtB} / \mathrm{AO}$ and visualized by a fluorescent microscope. At the control cultures, it was found that the cell nuclei were sharp, shiny and integrated, but at a concentration of 0.5 $\mathrm{mg} / \mathrm{ml}$ of the extract, treated cells contained condensed and fragmented chromatin. Fragmented chromatins were observed in all treated cell cultures.

The treated cells were studied by SEM under Fixed Aperture to reveal cell blebbing and fragmentation. The results showed normal shapes for controls, but in the concentration of $0.5 \mathrm{mg} / \mathrm{ml}$ of the DCMextract, the cells were globular and fragmented with condensed pieces. Furthermore, at $1 \mathrm{mg} / \mathrm{ml}$, the treated cells were perceived as shrunken, with irregular outlines and broken surfaces (Figure 2, 3A3C)

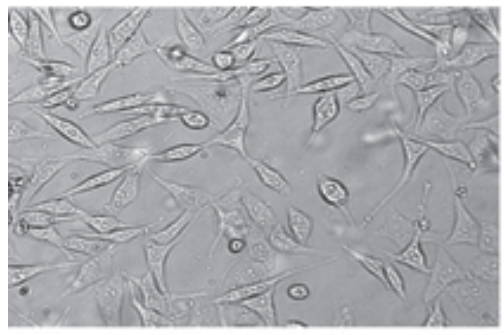

$1 \mathrm{~A}$

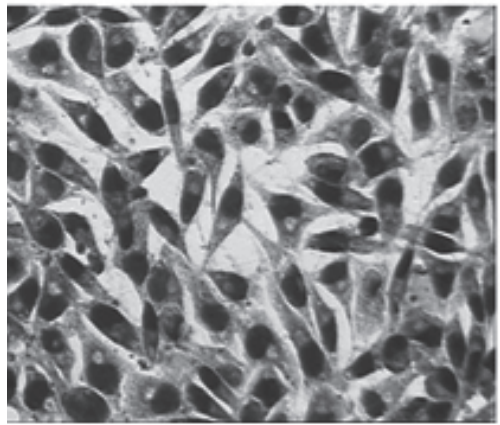

$2 \mathrm{~A}$



$3 \mathrm{~A}$

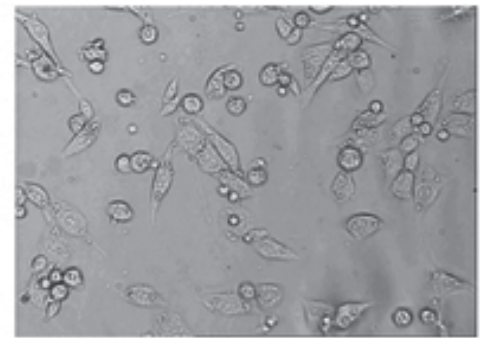

1B

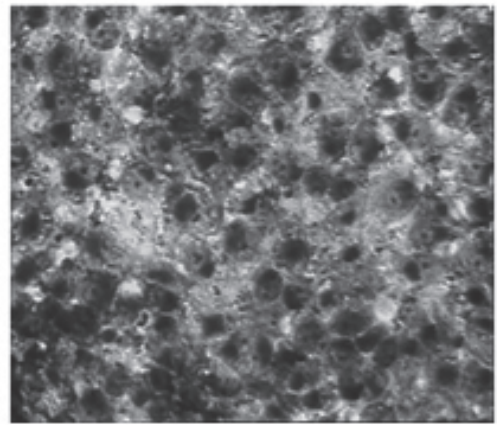

2B

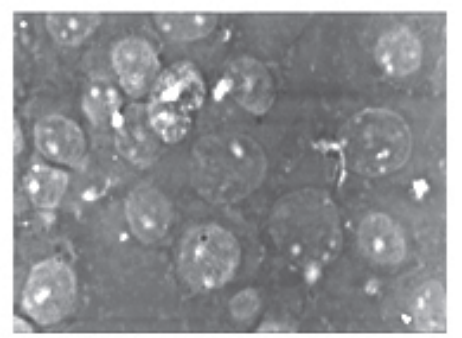

3B

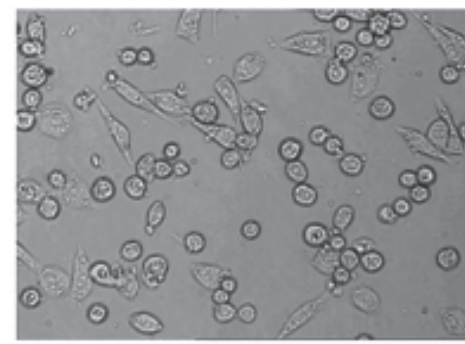

$1 \mathrm{C}$

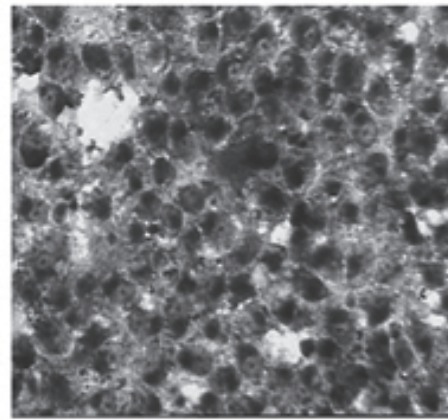

$2 \mathrm{C}$



$3 \mathrm{C}$

Fig. 2: The effects of DCM extract of P. uloptera on the morphology of McCoy cells cultured in RPMI 1640 for $24 \mathrm{~h}$. Upper row: Direct microscopy study, (1A)effect of $0 \mathrm{mg} / \mathrm{ml}$, (1B) $0.5 \mathrm{mg} / \mathrm{ml}$ and (1C) $1 \mathrm{mg} / \mathrm{ml}$ of the extract. Middle row: haematoxylin - eosin staining of treated cells, (2A) effect of $0 \mathrm{mg} / \mathrm{ml}$ and (2B) $0.5 \mathrm{mg} / \mathrm{ml}$ of plant extract and (C) effect of $50 \mu \mathrm{M}$ of Actinomicen D as positive control of apoptosis. Lower row: Scanning electron microscopy analysis, (A) Control, (B) Apoptotic cells $-0.5 \mathrm{mg} / \mathrm{ml},(\mathrm{C})$ Necrotic cells $-1 \mathrm{mg} / \mathrm{ml}$ 
Detection of DNA fragmentation was performed by agarose gel electrophoresis within $16 \mathrm{~h}$ after treatment with the DCMextract. The results showed that DNA fragmentation induction did not occur in the concentrations of $0.2 \mathrm{mg} / \mathrm{ml}$, but was significantly present at $0.5 \mathrm{mg} / \mathrm{ml}$. The intensity of fragmented DNA at $1 \mathrm{mg} / \mathrm{ml}$ was less than $0.5 \mathrm{mg} / \mathrm{ml}$ (Figure 3 ).

\section{DISCUSSION}

Using natural products to inhibit or repress malignant growth is one the goals of cancer chemoprevention. Previous studies have reported that defects in apoptotic pathways or repression of apoptosis contribute to expansion of cancer development (Korsmeyer, 1992; Miyashita \& Reed, 1993). Thus, agents that can eliminate abnormal clones by induction of apoptosis rather than merely slowing down their proliferation may have chemopreventive potential (Sun, 2001). It seems likely that rational strategies to manipulate cell suicide programs will produce new therapies that are less toxic and mutagenic than current treatment regimens (Lowe \& Lin, 2000).
Our results show that the DCM-extract of $P$. uloptera has significant antiproliferative and cytotoxic effects on McCoy cells. The concentration of $1 \mathrm{mg} / \mathrm{ml}$ of the extract showed $20 \%$ and $0 \%$ viability by MTT and trypan-blue exclusion test, respectively. In other words, this assay showed that $100 \%$ of cells absorbed the trypan-blue dye. This test is based on the principle that living cells possess intact cell membranes that exclude the dye, whereas dead cells do not (Strober, 2003). Rupture of the cellular membrane is one of the crucial criteria used to distinguish necrosis from apoptosis (Kim et al, 2001). Thus, it means that the cell membrane was disrupted and the cells died by necrosis at higher concentrations of the extract. A number of methods have been used by researchers to distinguish between apoptosis and necrosis. Assessments of membrane integrity with trypan blue dye exclusion are nonspecific unless morphological traits can be directly analyzed with the dyes (Allen, 1997). Direct microscopic study of the treated cell cultures noted changes in cell shape, discontinuity in cell-cell adhesion and slowing down of the growth rate in a dose dependent manner. Detailed studies using


Fig. 3: An example of DNA fragmentation pattern: DNA size marker - $1 \mathrm{~kb}$ standard (M), Negative control (A), $0.2 \mathrm{mg} / \mathrm{ml}$ (B), $0.5 \mathrm{mg} / \mathrm{ml}$ (C), $1 \mathrm{mg} / \mathrm{ml}$ (D), Positive control of apoptosis (E). 
hematoxylin -eosin staining showed that the morphology of the treated cultures with $0.5 \mathrm{mg} / \mathrm{ml}$ of the extract and Actinomycin D were alike. Actinomycin D is a classical anti-neoplastic drug that promotes induction of apoptosis. As well, following administration of $0.5 \mathrm{mg} / \mathrm{ml}$ of the extract, the changes in treated cells shapes, nucleus fragmentation and failure in absorption of EtB were observed by using fluorescent staining. As well, membrane blebbing and cell shrinkage were found by using SEM analysis. Thus, these findings clarified induction of an apoptosis pathway. Finally, because internucleosomal DNA crushing by undefined endonuclease activities is a highly distinguishable event and evidence of the early stage of apoptosis (Wyllie, 1980b), observation of significant and typical DNA fragmentation in the concentration of $0.5 \mathrm{mg} / \mathrm{ml}$ of the extract accurately confirmed induction of apoptosis in McCoy cell lines. Thus, these findings clearly confirmed that the DCM extract of $P$. uloptera effectively induces apoptosis and necrosis in moderate and higher concentrations, respectively. Identification and isolation of natural chemical agents from this extract and evaluation of their probable effects on cancerous cell lines is in progress.

\section{REFERENCES}

ADJEI AA, ROWINSKY EK, 2003. Novel anticancer agents in clinical development. Cancer Biology \& Therapy, 2: 5-15

ALLEN RT, HUNTER WJR, AGRAWAL DK, 1997. Morphological and Biochemical Characterization and Analysis of Apoptosis. Journal of Pharmacological and Toxicological Methods, 37: 215-228

DOYLE A, GRIFFITH JB, 1998. Cell and tissue culture: Laboratory procedures in biotechnology. John wiley and sons, Chichester

FRESHNEY RI, 2005. Culture of Animal Cells: A Manual of Basic Technique, 5rd ed. New York: John Wiley and Son

HANSEN MB, NIELSEN SE, BERG K, 1989. Reexamination and further development of a precise and rapid dye methods for measuring cell growth/cell kill. Journal of Immunological Methods, 119: 203-210

HONG YS, HAM YA, CHOI JH, KIM J, 2000. Effects of allyle sulfure compounds and garlic extract on the expression of Bcl-2 ,Bax and p53 in non small cell lung cancer cell lines. Experimental and Molecular Medicine, 32: 127-134

JACOBSON MD, WEIL M, RAFF MC, 1997. Programmed cell death in animal development. Cell, 88: 347-354

KIM H, YOU S, KONG B, FOSTER L, FARRIS J, FOSTER D, 2001. Necrotic cell death by hydrogen peroxide in immortal DF-1 chicken embryo fibroblast cells expressing deregulated MnSOD and catalase. Biochimca et Biophysica Acta, 1540: 137-146

KORSMEYER SJ, 1992. Bcl-2 initiates a new category of oncogenes: regulators of cell death. Blood, 80: 879-886

LOWE SW, LIN AW, 2000. A2poptosis in cancer. Carcinogenesis, 12: 485-495

MIYASHITA T, REED JC, 1993. Bcl-2 oncoprotein blocks chemotherapy-induced apoptosis in a human leukemia cell line. Blood, 81: 151-157

QI L, XU Z, LI Y, JIANG X, HAN X, 2005. In vitro effects of chitosan nanoparticles on proliferation of human gastric carcinoma cell line MGC803 cells. World gastroenterology, 11: 5136-5141

RAZAVI SM, ZAHRI S, NAZEMIYEH H, ZARRINI G, MOHAMMADI S, ABOLGHASMI M, 2009b. A furanocoumarin from Prangos uloptera, Biological effects. Natural product Research, In Press

RAZAVI SM, ZARRINI G, ZAHRI S, MOHAMMADI S, 2009a. Biological activity of Prangos uloptera DC. roots, a medicinal plant from Iran. Natural Product Research, inpress

RIBBLE D, GOLDSTEIN NB, NORRIS DA, SHELLMAN YG, 2005. A simple technique for quantifying apoptosis in 96-well plates. BMC Biotechnology, 5: 10.1186/1472-6750-1185-1112

RODRIGUEZ-NIETO S, ZHIVOTOVSKY B, 2006. Role of Alterations in the Apoptotic Machinery in Sensitivity of Cancer Cells to Treatment. Current Pharmaceutical Design, 12: 4411-4425

STROBER W, 2003. Trypan blue exclusion test of cell viability. In: Coligan JE, Kruisbeek AM, Margulies DH, Shevach WM, Strober W, eds, Current Protocols in Immunology, John Wiley and Sons, Inc

SUN S-Y, 2001. Apoptosis Induction by Chemopreventive Agents. Drug News Perspect, 14: 75

VIAN L, VINCENT J, MAURIN J, FABRE I, GIROUX J, CANO JP, 1995. Comparison of three in vitro cytotoxicity assays for estimating surfactant ocular irritation. Toxicology in Vitro, 9: 185-190

WATTERS D, LAVIN M, 2005. Modern Genetics: Signalling Pathways in Apoptosis. harwood academic publishers. The Queensland Institute of Medical Research

WYLLIE AH, 1980b. Glucocorticoid-induced thymocyte apoptosis is associated with endogenous endonuclease activation. Nature, 284: 555-556

WYLLIE AH, KERR JF, CURRIE AR, 1980a. Cell death the significance of apoptosis. International Review of Cytology, 68: 251-306

YELDJOU C, MOREE P, TECHOUNWOU PB, 2006 Dose and time-dependent response of human leukemia (HL-69) cells to Arsenic trioxide treatment. International Journal of Environmental Research And Public Health, 3: 136-140

ZHANG Q, WU J, HU Z, LI D, 2004. Induction of HL-60 apoptosis by ethyl acetate extract of cordyceps sinesis fungal mycelium. Life sciences, 75: 2911-2919 